\title{
A Solar-Energy Method for Reducing Coffee-Drying Costs
}

\author{
Allan L. Phillips ${ }^{1}$ \\ INTRODUCTION
}

During the past several years engineers from the Agricultural Engineering Department of this Agricultural Experiment Station have worked closely with cooperating farmers to design, construct, and operate coffeeprocessing facilities which evade many of the problems and inconveniences which have been associated with older methods of coffee processing. Recent testing and evaluation of equipment and techniques for on-the-farm processing of coffee have demonstrated the advantages of using an all-electric system, the principal features of which are a materials-handling pump for moving the product between processing stages, and a shallow bin-drier for carrying out the drying operation. A description of this system and its advantages has been reported by Boyce (1). ${ }^{2}$

The system successfully provides the advantages of low labor requirements, low initial cost for equipment, simplicity of operation, and the production of a dried parchment coffee of high quality. Although the electric heating elements used in the drier provide clean heated air, are easily controlled, and are inexpensively and easily installed, their operation results in quite high electricity costs at current rates. During one period of observation it was found that the electricity consumption was $37 \mathrm{kw} .-\mathrm{hr}$. per hundredweight of market coffee produced, and, apparently, electricpower requirements usually have exceeded this figure in the all-electric installations. A significant reduction in these electricity costs would further enhance the economic advantages of such modernized coffee-processing facilities.

The use of a solar heat-collector to supply heated air to the drying bin was considered. Methods for utilizing solar heat for drying grain have been developed during the past several years by Buelow (4). The result of his work gave evidence that solar heat could be used successfully in the coffee-drying operation by employing a heat-collector like the one shown in figure 1.

The sketch in figure 1 shows how a roof can be constructed so as to form

${ }^{1}$ Assistant Agricultural Engineer, Agricultural Experiment Station, University of Puerto Rico, Rio Piedras, P.R. The author wishes to acknowledge the contribution of $\mathrm{Mr}$. Domingo Justiniano who, as cooperating farmer in this project, made the experimental work possible.

${ }^{2}$ Italic numbers in parentheses refer to Literature Cited, p. 235. 
a solar heat-collector. Sheathing such as plywood or hard board is fastened to the top of 2-x-6-inch rafters. Horizontal 2-x-2-inch rafters are placed on top of the sheathing, and sheet-metal roofing is nailed to the rafters. The upper surface of the roof is coated with black-asphalt roof paint to enhance solar-energy absorption. Openings at each end of the roof provide inlets for air. The air is drawn into the air-chamber beneath the drying bin. The air then moves up through the coffee and leaves the building through doors or windows in the far side.

An alternative method of construction is to place the sheathing on the bottom, and the sheet-metal roofing on the top of the rafters, using the

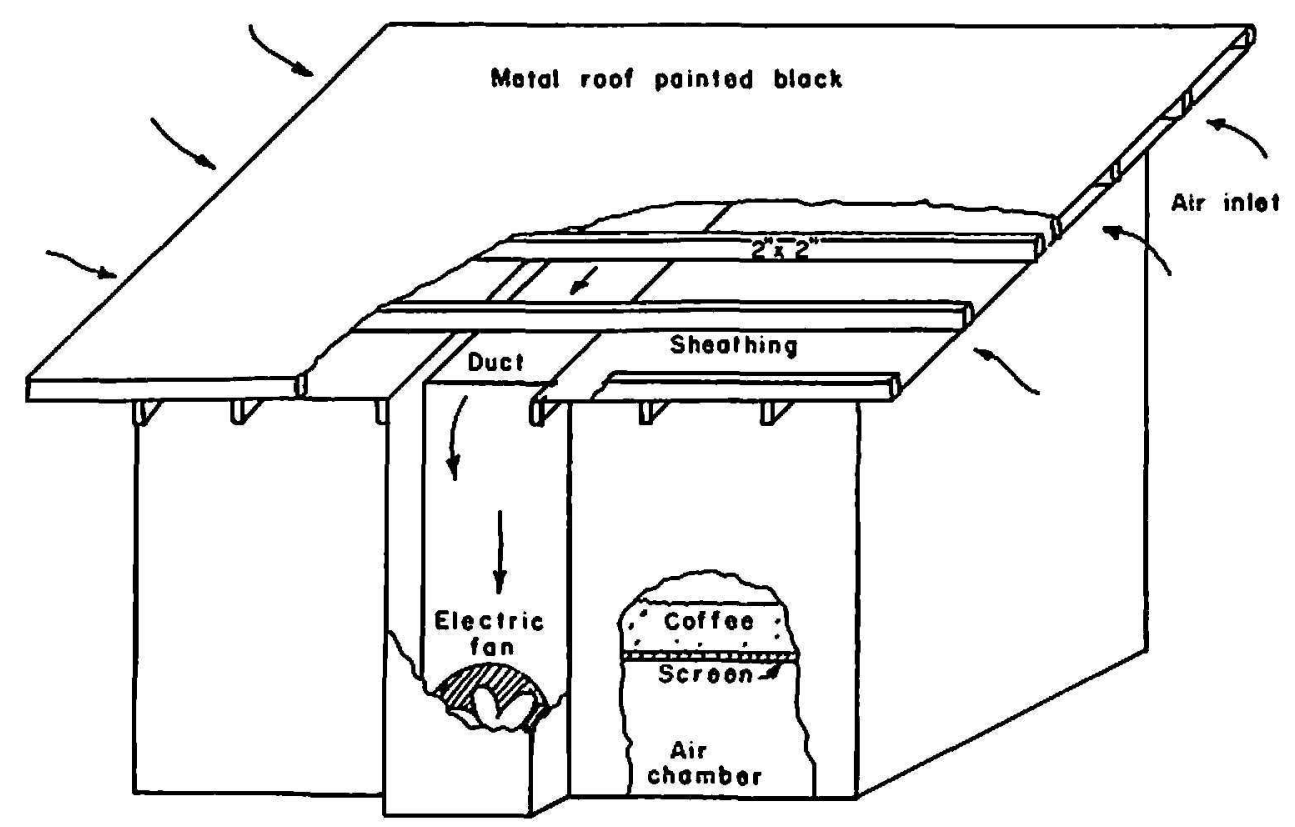

Fra. 1.-A diagram showing how the roof of a coffec-processing building can be used as a solar heat-collector.

space between for the air passage, and having a duct across the lower edge of the roof to collect the air and convey it to the fan.

To obtain experimental verification of the performance of such a solarcollector, a project was undertaken to construct and evaluate an installation that utilizes solar energy to provide heated air for drying coffee.

\section{MATERIALS AND METIOUS}

$\Lambda$ cooperative agreement was entered into between this Agricultural Experiment Station and a cooperating farmer from the Mayagüez area of Puerto Rico in May 1962. The Station provided the design of a building and facilities, and technical information regarding the construction and operation. The cooperating farmer constructed the building according to the Station's recommendations and operated it throughout the 1962 har- 
vest season, allowing the Station to obtain data necessary for an evaluation of the usefulness of this method of harnessing solar energy.

A building with dimensions of $20 \times 30$ feet was constructed, and equipped to process 200 hundredweights of market coffee per year. During the first season of operation 150 hundredweights were processed. It is ex-

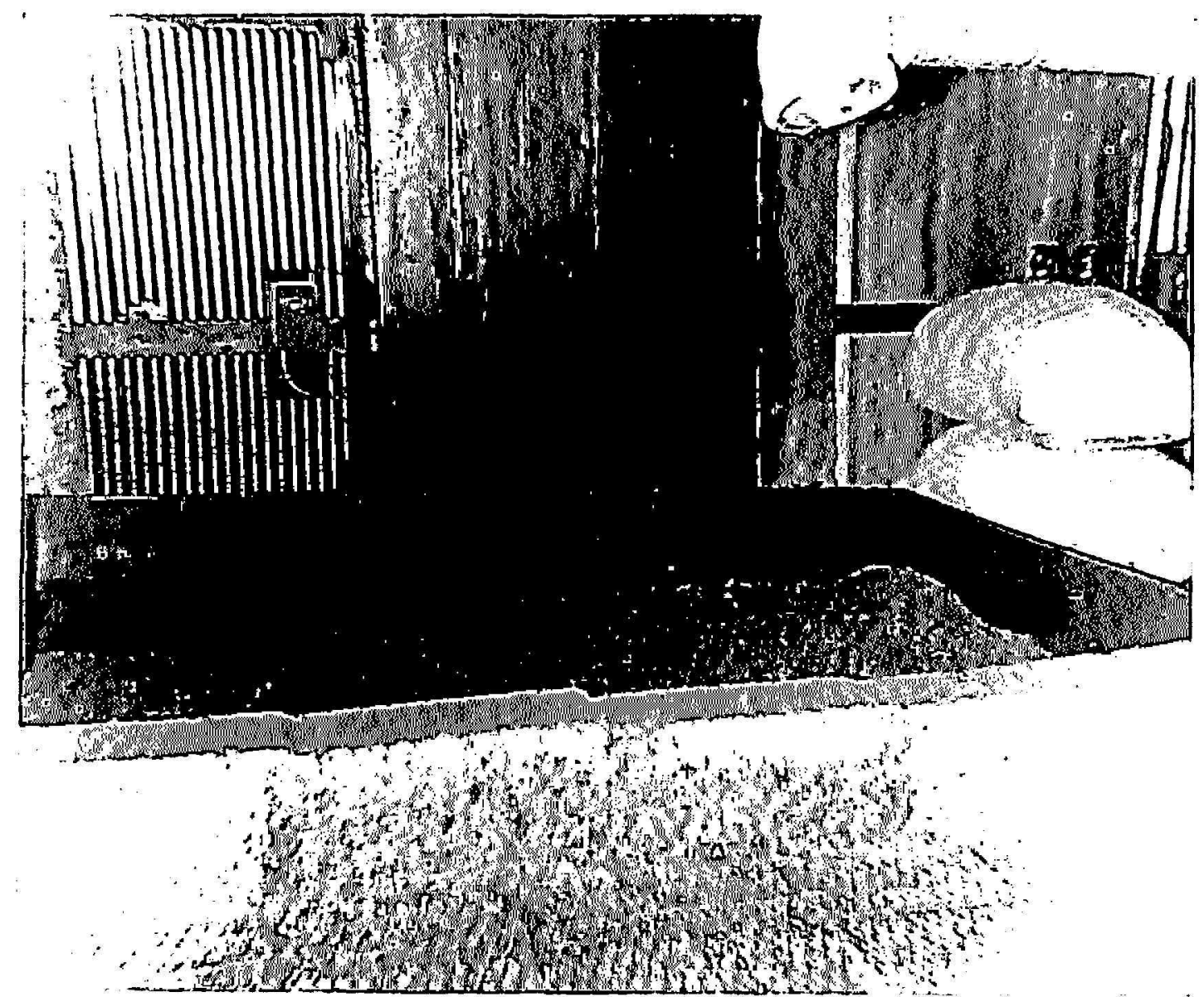

Fia. 2.-Drying facilities, showing the empty predrier in the foreground, the drior. which is partly filled with parchment coffee, and the duct that brings air down from the solar heat-collector to the fan on the far side of the drier. Washed parehment coffee comes to the predrier through the $2^{2}{ }_{2}$-inch pipe seen in the upper right corner of the illustration. The switch on the wall near the duct controls the heating elements.

pected that the annual production will increase to 200 hundredweights in the next harvest season as more young 1 rees come into full production. The cost of construction was approximalely \$2,821, including $\$ 1,356$ for equipment, $\$ 965$ for construction materials, and $\$ 500$ for labor.

The operation of drying parchment coffee was carried out in lwo stages in the drying bins shown in figure 2. The first stage was the predrior, which included a shallow bin, $51,2 \times 5 \frac{1}{2}$ feet, with the bott om made of wire mesh supported by expanded metal on steel rods. Attached to the air-chamber beneath the bin was an 18-inch-diamcter axial flow-fan powered by a 1! 1/2- 
horsepower electric motor. The washed parchment was pumped into this predrier, and the wash-water was allowed to drain down through the layer of parchment coffee and run through a pipe back to the washing tank. The fan moved air down through the coffee and out of the building. The downward movement of the air supplements the force of gravity and causes the wash-water to drain out of the parchment, and the predrier contained skin-dry parchment coffee within 2 or 3 hours. The air used in the predrier was not heated.

The final stage of drying was also done in a shallow bin, $5 \frac{1}{2} \times 5 \frac{1}{2}$ feet, with construction similar to that of the predrier. In the drier a $1 / 2$-horsepower motor was used to drive an 18-inch-diameter axial flow-fan which forced heated air upwards through the layer of parchment coffee. Four electric fin-strip heating elements, each having a power consumption of $1,300 \mathrm{w}$. were installed in the air-duct just upstream from the fan. Thus air was heated first, as it passed through the solar collector, and then additional heat was supplied by the electric heating elements. Air should be used at about $120^{\circ} \mathrm{F}$. to dry parchment coffee in shallow bins. Using higher temperatures will result in uneven drying and may affect the flavor of the finished product, whereas using lower temperatures will result in a slower rate of drying and, consequently, a lesser capacity for the system.

The roof was constructed with a 3-inch air-passage between the sheetmetal roofing and the sheathing. The outside surface was painted with black-asphalt roof paint. The roof had a slope of 6.3 degrees towards the south. The effective solar-collector area was approximately 600 square feet.

A pyrheliograph was used to record the incident solar energy impinging on the roof. Air temperatures were measured at four stations: 1, Ambient; 2 , in the air-duct upstream from the electric heaters; 3 , in the air-chamber beneath the bin; 4 , exhaust air at the surface of the parchment coffee in the bin.

\section{RESULTS AND OBSERVATIONS}

Figure 3 shows the daily totals of solar energy falling on a horizontal surface at the location of the coffee-processing installation in Barrio Anones, located about $6 \mathrm{~km}$. due west of the town of Las Marias. The data were taken during the period September 13 through November 30, 1962. The accumulated daily totals of incident solar energy were obtained by measuring with a planimeter the area under the tracing on the pyrheliograph charts, which provided a continuous recording of energy per unit area.

On several days the charts were incomplete, and for these days the averages for the various months were substituted in preparing the graph in figure 3. For the period September 13 through September 30, the average radiant energy incident on 1 square foot of horizontal surface was 1,904 
B.t.u. per day. During the month of October the average energy was 1,861 B.t.u./ft. ${ }^{2}$ per day, and during November, 1,715 B.t.u./ft. ${ }^{2}$ per day. Although these figures are not extremely accurate, they provide a good indication of the amount of solar energy which can be expected in this area during the harvest season, and such information on solar-energy availability in Puerto Rico is very scarce at present.

This location has a high rainfall and much cloud cover during this time of year. Nevertheless, there were always a few hours of bright sunshine each day.

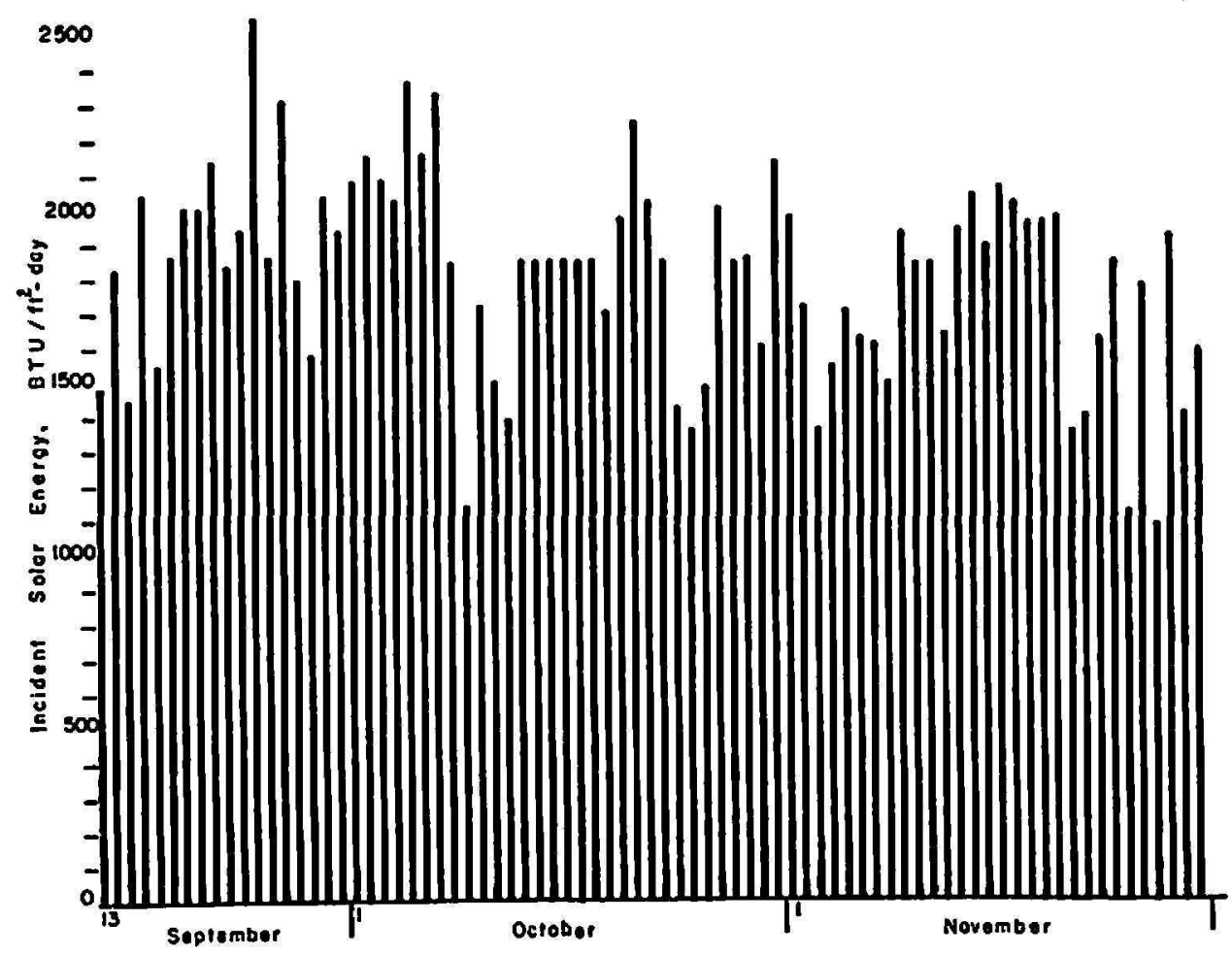

Fra. 3.-Daily totals of solar energy incident on a horizontal surface at the location of the experimental cuffee-drying facilities, September through November.

The magnitude of these values for the quantity of solar energy available brings into view the great potential of the sun as a source of heat. The collector area of 600 square feet was receiving more than a million B.t.u. of radiant energy per day, equivalent to about $300 \mathrm{kw}$.-hr. of energy, which would cost $\$ 6.00$ per day if it were purchased in the form of electric current at present local rates. Of course, not all of this incident energy can be converted into heat; yet a substantial portion of it can be used, as was demonstrated by the increases in temperature in the air as it moved through the solar-collector.

The increase in the temperature of the air as it passes through the col-

21 British thermal unit $=2.930 \times 10^{-4} \mathrm{kw} .-\mathrm{hr}$. 
lector is influenced primarily by the intensity of solar energy striking the collector surface, the ratio of the air-flow rate to the area of the collector, and the design of the collector. Other factors, such as wind velocity, have a minor influence. Buelow (4) developed an equation, based on experimental results, for the performance of solar heat-collectors constructed like the one used in this project. His equation was as follows:

$$
t=0.108 R\left(1-e^{-8.08 / v}\right)
$$

where $t$ is the increase in air temperature in the collector, ${ }^{\circ} \mathrm{F}$.

$R$ is the incident solar energy in B.t.u. per square foot per hour, and

$V$ is the air-flow rate in cubic feet per minute per square foot of collector area.

Temperatures were measured in the coffee-drying installations when the drier contained an 8-inch-deep layer of parchment. The air-flow rate was approximately 2,700 c.f.m., corresponding to a value of 4.5 for $V$. $\Lambda$ number of temperature measurements were made and, when plotted against the corresponding values of incident solar energy, $R$, gave the following equation:

$$
t=0.0831 R
$$

(equation II)

This is slightly lower than the performance predicted by Buelow's equation, probably because of differences in the design of his collector as well as inaccuracies in the measurements, but, nevertheless, it shows that substantial temperature increases were being achieved.

During the middle hours of a clear day the air tempcrature was increased from $83^{\circ}$ to $110^{\circ} \mathrm{F}$. in the solar heat-collector. The electric heating elements, consuming $5,200 \mathrm{w}$. of electric power, provided an additional temperature increase of about $7^{\circ} \mathrm{F}$. This combination provided very favorable conditions for achieving a satisfactory drying operation, with the air at $117^{\circ} \mathrm{F}$. as it entered the coffee. With deeper layers of coffee in the dryingbin the air-flow was reduced and, as a result, the air-temperature increases were greater in both the solar heat-collector and the electric heaters. With 12 inches of coffee in the dryer the solar heat-collector alone could raise the air temperature to close to $120^{\circ} \mathrm{F}$.

The electric-power consumption for all the processing operations was approximately $20 \mathrm{kw}$.-hr. for each hundredweight of dried coffee produced. This can result in a saving in electricity costs of $\$ 0.50$, or more, per hundredweight, or a yearly saving of $\$ 100$, when 200 hundredweights are processed. The additional cost of construction necessary to provide a solar heat-collector in the roof of the building was also approximately $\$ 100$. Therefore, this additional installation cost is recovered by reductions in operating costs in one season of operation. 


\section{DISCUSSION AND CONCLUSIONS}

The first attempt to utilize a solar heat-collector to provide heated air for drying coffee has demonstrated that significant reductions in processing costs can be achieved. It would be worthwhile for other coffee farmers to take advantage of this inexpensive source of heat.

In designing coffee-drying facilities which incorporate a solar heat-collector, the sizes of the drying-bins, the fans, and the collector area must be selected according to the quantity of coffee to be processed, in order to achieve an efficient operation. In a separate project being carried out in the Agricultural Engineering Department of this Station, data have been obtained on the effects of air-flow rates, air temperature, and depth of coffee, on drying efficiency. It has been shown that a layer of coffee 12 inches deep can be effectively dried from 50 - to 12 -percent moisture content (wet basis) within 24 hours, using air temperatures between $100^{\circ}$ and $120^{\circ} \mathrm{F}$. and air-flow rates of 120 cubic feet per minute per square foot of bin area (3). Although these data have not yet been completely analyzed, enough information has been obtained from the experiments and observations to make recommendations which can serve as a guide for designing drying facilities.

First, the amount of coffee to be processed must be known, and generally, a farmer knows that his production will be in terms of hundredweights (or quintales) of coffee produced in one season. A study of harvesting records has shown that the maximum daily production in a season is approximately 2.5 percent of the yearly production. For example, if 100 hundredweights are processed in a year, 2.5 hundredweights will be processed in the busiest day of that year. Therefore the drier must be designed to dry at a rate of 2.5 hundredweights per day for each 100 hundredweights processed per year. The drying bin should contain about a 12-inch layer of coffee when operating at full capacity. The bulk density of dry parchment coffee is 27 pounds per cubic foot. Therefore, 3.7 square feet of bin area will be required for each hundredweight of coffee. A general guide for small and medium farms is to have 10 square feet of drier area for each 100 hundredweights produced yearly.

The fan should be able to deliver at least 100 cubic feet per minute per square foot of drier area against a water-gage pressure of 1 -inch. This pressure resistance includes a pressure drop of 0.85 inches in the coffee and 0.15 inches in the solar heat-collector (2). For example, if the bin area is 20 square feet, the fan must be able to deliver 2,000 c.f.m. at 1 -inch pressure. The predrier bin should have approximately the same dimensions as the drier bin. The predrier fan should be powered by a motor no smaller than $1 \frac{1}{2}$ horsepower.

In construeting the solar heat-collector it is convenient to use the en- 
tire roof area available. In general, a building which houses the drying bins, the processing equipment, and some storage space, will be of about the proper size to provide an economical solar heat-collector. It is important that the roof be oriented with a small inclination toward the south, and not be shaded by trees or other buildings.

The results of this project so far indicate that it is not practicable to depend entirely on solar energy for heating the drying air. Electric heating elements should also be provided, so the drying operation can be carried

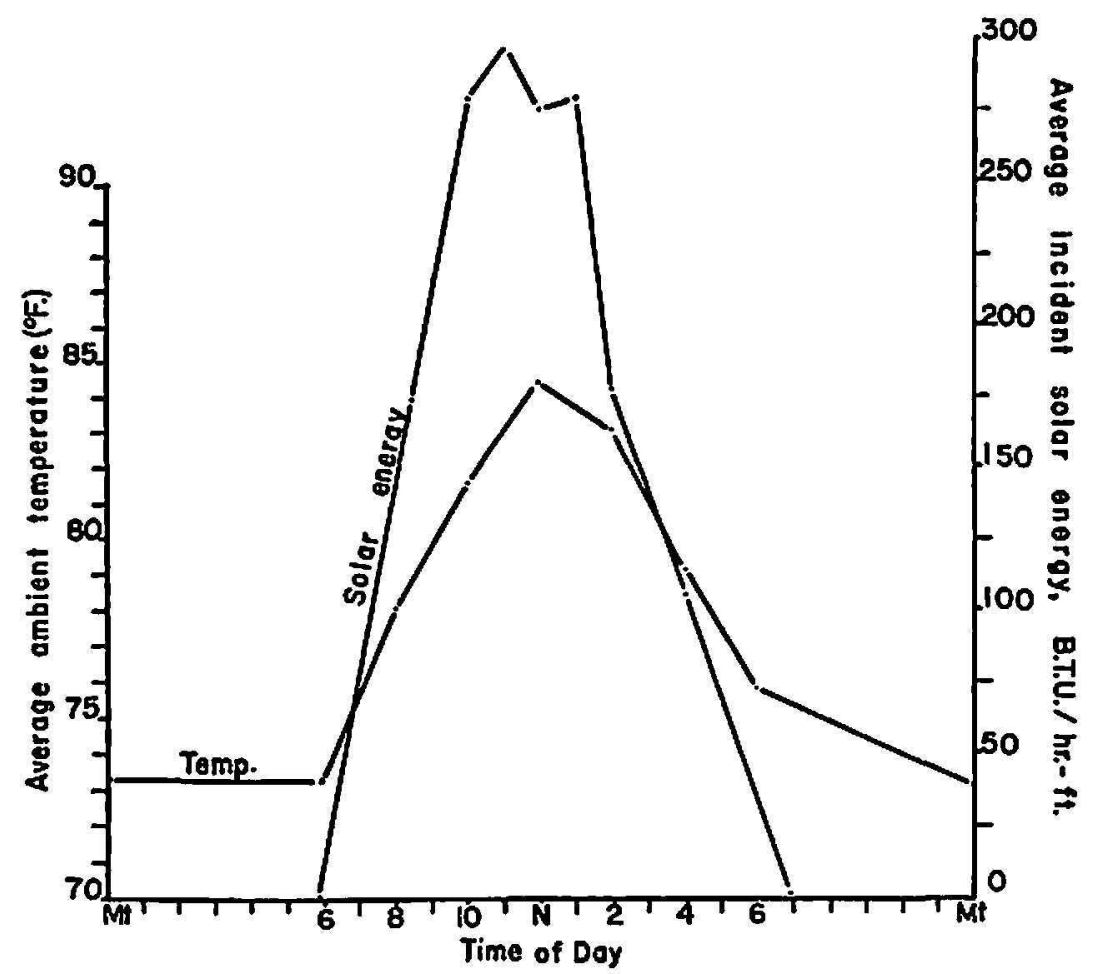

Fra. 4.-Average values of ambient temperature and of incident solar energy at different hours of the day during the period Sept. 13 to Sept. 30, 1962, at the location of the experimental coffee-drying facilities.

out during periods of little sunshine as well as during the night when necessary. With careful management much of the coffee can be dried without using the electric heating elements, thereby keeping the operating costs low. Nevertheless, it is desirable to have electric heat available, and heating elements should be installed which can provide up to 5,000 w. for each 100 hundredweights processed yearly. It was found that it would be desirable to increase the electric heating capacity in the experimental installation.

The graph in figure 4 shows the average values of the ambient temperature thoughout the day during the period Scptember 13 through September 30 . The average quantities of incident solar energy are shown also for this period. It is apparent from the values shown that very good collector performance would be needed in order to raise the air temperature from am- 
bient to the desired drying temperature for a period of several hours each day. One way to obtain higher temperatures is to construct the solar heatcollector by placing a glass sheet or transparent plastic film about 2 inches above the metal surface, using the space between for an air passage. This type of collector would provide about double the temperature rises obtained in the no-glass collector, but the disadvantages are obvious in that initial construction costs, as well as maintenance costs would be higher. Experiments using plastic materials are planned for the future to investigate their possibilities further for use in solar heat-collectors for coffee-drying installations.

\section{SUMMARY}

1. Modern coffee-processing facilities that have been developed recently have provided the features of low equipment costs and reduced labor requirements, but are somewhat expensive to operate when electric power is used entirely to heat the drying air.

2. The use of solar energy as a heat source was considered, since previous research where solar heat was used to dry other crops indicates that solar heat-collectors could also be used successfully for drying coffee.

3. An experimental processing facility which employs a solar heat-collector was built and operated, and it has been demonstrated that worthwhile reductions in operating costs can be achieved through the use of solar energy.

4. It was concluded that other coffee producers could economically use solar heat-collectors to reduce electricity costs. Drying facilities should be designed using the following as guides:

A. Provide 10 square feet of drying-bin area for each 100 hundredweights of coffee produced yearly.

B. Install a fan which will deliver 100 c.f.m. per square foot of bin area against a static pressure of 1 -inch water gage.

C. Construct the solar heat-collector according to the specifications presented in figure 1.

D. Install electric heating elements which provide up to $5,000 \mathrm{w}$. for each 100 hundredweights processed yearly.

\section{RESUMEN}

1. Las facilidades modernas que se han desarrollado recientemente para el beneficiado del café se caracterizan por el bajo costo del equipo y la reducción en la mano de obra, pero su funcionamiento es algo costoso cuando sólo se utiliza la corriente eléctrica para calentar el aire secante.

2. Se decidió entonces aprovechar la energía solar como fuente de calor, pues cuando se usó ésta en investigaciones previas para secar otros productos 
se demostró que los colectores de calor solar también podrían usarse con éxito para secar café.

3. Se construyó y se puso en funcionamiento una planta experimental para el beneficiado del café, equipada con un colector de calor solar, demostrándose que de esta manera se pueden reducir considerablemente los costos de operación.

4. Como resultado de estos experimentos se llegó a la conclusión que los caficultores podrían usar también colectores de calor solar para reducir los gastos de corriente eléctrica. La planta para secar debe diseñarse según las siguientes especificaciones:

A. Provéanse 10 pies cuadrados de área secadora por cada 100 quintales de café que se produzca anualmente.

B. Instálese un abanico que produzca 100 pies cúbicos por minuto por pie cuadrado de área secadora contra una presión estática de 1 pulgada de agua.

C. Constrúyase el colector de calor solar de acuerdo con las especificaciones que aparecen en el dibujo de la figura 1.

D. Instálense elementos calentadores eléctricos que provean hasta 5,000 vatios por cada 100 quintales de café que se beneficie anualmente.

\section{LITERATURE CITED}

1. Boyce, D. S., Coffee processing rationalized for the medium farm, World Crops 14 268-74, 1962.

2. Boyce, D. S., and Pérez Fonrodona, A. A., Observations on the resistance to vertical airflow of green and parchment coffee, J. Agr. Univ. P.R. 45 (1) 55-64, 1962.

3. Boyce, D. S., and Phillips, A. L., unpublished data.

4. Buelow, F. H., Drying Grain with Solar Heated Air, Q. B. Mich. Ayr. Expt. Sta., November 1058. 